\title{
TELAAH GAGASAN PARAMADINA TENTANG PERNIKAHAN BEDA AGAMA
}

\author{
Iffah Muzammil \\ Universitas Islam Negeri Sunan Ampel Surabaya, Indonesia \\ E-mail: ivamuzammil@yahoo.co.id
}

\begin{abstract}
This article deals with the idea of interfaith marriage proposed by the Endowment Foundation of Paramadina (Yayasan Wakaf Paramadina) established by Nurcholish Madjid and his colleagues. The activists of this foundation offer ideas to give freedom to every Muslim, both male or female, to marry a non-Muslim, regardless of their religion and their faith. This idea is at least starting from two basic assumptions; first, that the Qur'ân only prohibits marriage with Arab polytheists which are almost certainly does not exist now; and second, that all religions and faiths that exist today are People of the divine Book. This idea had never been previously proposed by other scholars who only allow the marriage of male Muslim with woman from the people of the Book (Jews and Christians). Even the existing Indonesian law requires that marriage should be performed by a pair of co-religionists. This idea refers to the consideration of social relationships, namely the creation of interreligious harmony, but apparently tend to ignore the interests of the faith.
\end{abstract}

Keywords: Interfaith marriage; polytheists; people of the Book.

\section{Pendahuluan}

Keinginan agar pernikahan beda agama dilegalkan di Indonesia akhirnya dikandaskan oleh keputusan hakim konstitusi. Meskipun sudah mendengarkan keterangan sejumlah ahli dan saksi serta perwakilan organisasi keagamaan, keinginan pemohon tak terkabul. Mahkamah Konstitusi (MK) menolak pengujian pasal 2 ayat (1) UU No. 1 Tahun 1974 tentang perkawinan mengenai syarat sahnya perkawinan terkait kawin beda agama. MK menganggap pasal 2 ayat (1) UU Perkawinan sama sekali tidak bertentangan dengan UUD 1945. "Permohonan pemohon tidak beralasan menurut hukum, menyatakan 
menolak permohonan para pemohon untuk seluruhnya”, ucap Ketua Mahkamah Konstitusi, Arief Hidayat, saat membacakan putusan bernomor 68/PUU-XII/2014 di MK, Kamis (18/6/2015). ${ }^{1}$

Dengan keluarnya keputusan $\mathrm{MK}$, maka seluruh instansi pemerintah mulai pusat hingga daerah harus konsisten tidak melayani pernikahan beda agama, termasuk dinas pencatatan sipil. Menurut Dirjen Bimas Islam Kemenag, Machasin, keputusan tersebut pada prinsipnya menguatkan ketentuan yang selama ini dijalankan pemerintah, bukan membuat perubahan atau pun ketentuan baru. Adanya sinyalir kelompok masyarakat yang menfasilitasi pernikahan beda agama tidak boleh terjadi lagi, karena keputusan MK bersifat final. $^{2}$

Perdebatan tentang keabsahan pernikahan beda agama sejatinya telah terjadi sejak era sahabat. Sebuah riwayat menyatakan bahwa 'Uthmân b. 'Affân menikahi Naylah bint al-Farâfisah, seorang Nasrani yang kemudian masuk Islam. Namun ketika Hudhayfah menikahi seorang Yahudi, ia diperintahkan 'Umar b. al-Khațâb untuk menceraikannya. ${ }^{3}$ Sedangkan Ibn 'Umar juga tegas berpendapat bahwa menikahi wanita Ahli Kitab haram. ${ }^{4}$ Pandangan ini berbeda dengan pandangan jumbûr yang menetapkan bahwa seorang pria Muslim boleh menikahi wanita Ahli Kitab, sebaliknya wanita Muslimah tidak boleh menikahi pria Ahli Kitab. ${ }^{5}$ Namun demikian, hampir seluruh ulama sepakat bahwa menikahi musyrik non-Ahli Kitab haram. ${ }^{6}$

Perdebatan seputar keabsahan pernikahan beda agama tak kalah panasnya di Indonesia. Sebelum MK mengeluarkan keputusan pengharaman pernikahan beda agama, Majelis Ulama Indonesia

\footnotetext{
1 http://www.hukumonline.com/berita/baca/lt55828be906c8b/inilah-babak-akhirjudicial-review-kawin-beda-agama, diakses tgl 20 Juni 2015.

2 Jawa Pos, Semua Instansi Dilarang Layani Nikah Beda Agama, 22 Juni 2015, 3.

3 Wahbah al-Zuhaylî, al-Figh al-Islâmî wa Adillatuh, Vol. 9 (Damaskus: Dâr al-Fikr, 2004), 6655.

4 Muhammad 'Alî al-Ṣâbûnî, Rawầi' al-Bayân: Tafsîr Âyât al-Aḅkâm, Vol. 1 (Damaskus: Muassasat Manâhil al-'Ìrfân, 1980), 287.

${ }^{5}$ al-Zuhaylî, al-Fiqh al-Islâmî, 6651.

${ }^{6}$ Abû Ja'far al-Ṭabarî, Jâmi` al-Bayân fî Ta'wîl al-Qur'ân, Vol. 4 (t.t.: Mu'assasat alRisâlah, 2000), 362.
} 
(MUI) juga telah mengeluarkan fatwa tentang haramnya pernikahan beda agama, baik bagi wanita maupun laki-laki Muslim. ${ }^{7}$

Pandangan ini berbeda dengan "mazhab" yang dianut Yayasan Wakaf Paramadina. Dalam buku yang diterbitkannya, Fiqib Lintas Agama, kelompok ini mengemukakan gagasan "hendaknya pernikahan beda agama secara lebih luas diperbolehkan, apapun agama dan aliran kepercayaan yang dianutnya". ${ }^{\circ}$

Yayasan Wakaf Paramadina adalah sebuah lembaga keagamaan (Islam) yang berkecimpung dalam kajian keagamaan dan sosial ${ }^{9}$ yang didirikan pada 31 Oktober 1986 di Jakarta oleh para tokoh cendekiawan dan wiraswastawan muda Indonesia, antara lain Nurcholish Madjid, Dawam Rahardjo, Abdul Latif, dan lain-lain. Pandangan dasar yayasan ini adalah integrasi keislaman dalam keindonesiaan. Paramadina dibiayai oleh anggota dan kontribusi para dermawan. Salah satu program unggulannya adalah Klub Kajian Agama (KKA). Yayasan ini belakangan mendirikan Universitas Paramadina, yang berdiri pada $1998 .^{10}$

Di antara buku-buku terbitan Paramadina adalah Fiqib Lintas Agama, Membangun Masyarakat Inklusif-Pluralis, dan lain-lain. Dalam buku yang ditulis Nurcholish Madjid, Zainun Kamal, Komaruddin Hidayat, Masdar F. Mas'udi, Kautsar Azhari Noer, Budhy Munawar Rachman, dan Ahmad Gaus ini, Paramadina mengajukan gagasangagasan inklusifnya terkait hubungan Muslim dengan non-Muslim, salah satunya tentang hukum pernikahan beda.

Pernikahan beda agama yang dimaksud dalam artikel ini adalah pernikahan yang dilakukan oleh seorang Muslim/Muslimah dengan seorang Musyrik atau Ahli Kitab. Hampir seluruh ulama sepakat bahwa pernikahan dengan laki-laki/wanita musyrik hukumnya haram. ${ }^{11}$ Namun mereka berbeda pendapat mengenai hukum pernikahan dengan Ahli Kitab.

\footnotetext{
7 Abdusshomad Buchori, et.al., 101 Masalab Hukum Islam: Sebuah Produk. Fatwa Majelis Ulama Indonesia (t.t.: MUI Jatim dan Pusataka Dai Muda, 2003), 128.

${ }^{8}$ Mun'im A. Sirry, "Kawin Beda Agama”, dalam Mun'im A. Sirry (ed.), Fiqib Lintas Agama, Membangun Masyarakat Inklusif-Pluralis (Jakarta: Yayasan Wakaf Paramadina, 2004), 164.

${ }^{9}$ https://id.wikipedia.org/wiki/Yayasan_Paramadina, diakses tanggal 29 Juni 2015.

10 http://paramadina.or.id/, diakses tanggal 29 Juni 2015

11 Abû 'Umar Yûsuf b. 'Abd Allah b. Muhammad b. 'Abd al-Barr b. 'Âșim alQurtubî, al-Kâfî fî Fiqh Abl al-Madînah al-Mâlikể, Vol. 2 (Riyad: Maktabah Riyậ alHadîthah, 1980), 543. Lihat pula 'Alî b. Muhammad al-Rubâ'î al-Lakhmî, al-Tabsirah,
} 
Persoalannya adalah siapakah yang disebut musyrik dan Ahli Kitab? Apakah keduanya merupakan kelompok yang sama atau berbeda? Persoalan ini menjadi perdebatan di kalangan ulama. Ijtihad Paramadina juga berangkat dari dua konsep dasar tersebut.

\section{Perspektif al-Qur'ân tentang Musyrik dan Ahli Kitab}

Dalam pandangan agama, musyrik adalah seseorang yang mempercayai adanya Tuhan selain Allah, atau suatu aktivitas yang bertujuan utama ganda, pertama kepada Allah, dan kedua kepada yang lain. Berdasarkan pandangan tersebut, semua yang menyekutukan-Nya adalah musyrik, termasuk Kristen yang mempercayai Trinitas. ${ }^{12}$ Atas dasar pandangan itu pula, sebagian ulama menyatakan bahwasanya Ahli Kitab termasuk kelompok musyrik. ${ }^{13}$ Pendapat ini sejalan dengan pendapat Ibn 'Umar. ${ }^{14}$

Fakhr al-Dîn al-Râzî memperkuat pendapat tersebut dengan menyatakan bahwa Ahli Kitab adalah musyrik. Ada beberapa argumen yang dikemukakan, antara lain: pertama, Q.S. al-Tawbah [9]: 30-31 yang menyebutkan bahwa mereka melakukan perbuatan syirik. Kedua, Q.S. al-Nisâ' [4]: 48 yang menyebutkan bahwa Allah mengampuni seluruh dosa kecuali dosa syirik. Seandainya Yahudi dan Nasrani tidak termasuk musyrik, tentunya Allah akan mengampuninya. Jika ternyata Allah tidak mengampuninya, berarti mereka memang musyrik. Ketiga, Q.S. al-Mâidah [5]: 73 menunjukkan bahwa mereka menetapkan adanya banyak Tuhan. Keempat, hadith Nabi:

$$
\begin{aligned}
& \text { إذا لقيت عددا من المشركين فادعهم إلى الإسلام ، فإن أجابوك فاقبل منهم ، وإن أبوا فادعهم إلى }
\end{aligned}
$$

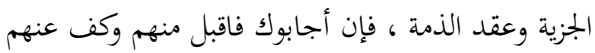

Hadîth tersebut menyebutkan bahwa ahli jiazyah dan dhimmah adalah musyrik, sementara Yahudi dan Nasrani adalah ahli jizyah dan dhimmah. Kelima, Abû Bakr al-'Așam berkata, "siapa saja yang menentang Muhammad adalah musyrik, karena menganggap bahwa mukjizat itu sihir yang berasal dari setan yang berarti percaya ada

\footnotetext{
Aḥmad Abd Karîm Najîb (ed.), Vol. 5 (Qatar: Wizârat al-Awqâf wa al-Shu'ûn al'Arabîyah, 2011), 2113.

${ }^{12}$ M. Quraish Shihab, Tafsir al-Mishbah, Vol. 1 (Jakarta: Lentera Hati, 2007), 473-474.

13 al-Ṭabarî, Jâmi' al-Bayân, Vol. 4, 362.

14 al-Ṣâbûnî, Rawâ'i al-Bayân, Vol. 1, 287.
} 
makhluk yang mampu menciptakan sesuatu di luar kemampuan manusia selain Allah". ${ }^{15}$

Pandangan tersebut ditolak oleh Paramadina. Menurut Paramadina, terdapat perbedaan yang jelas antara Musyrik dan Ahli Kitab. Dalam analisisnya, Paramadina menyebutkan adanya ayat-ayat al-Qur'ân yang membedakan Ahli Kitab dengan musyrik, yaitu Q.S. al-Baqarah [2]: 105 dan al-Bayyinah [98]: 1:

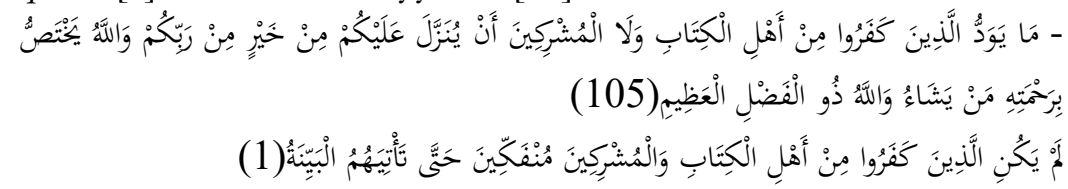

Dalam dua ayat tersebut, al-Qur'ân menggunakan kata penghubung wâw antara kafir Ahli Kitab dan kafir musyrik. Hal tersebut menunjukkan bahwa dua kata itu memiliki makna berbeda. ${ }^{16}$

Di samping itu, ada beberapa jenis kekafiran yang disebutkan alQur'ân di antaranya, 1) kafir ingkar, 2) kafir jubud, 3) kafir munafik, 4) kafir syirik, 5) kafir nikmat, 6) kafir murtad, dan 7) kafir Ahli Kitab. ${ }^{17}$ Dari beberapa jenis kekafiran di atas, menurut Paramadina semakin terlihat jelas bahwa kafir Musyrik berbeda dengan kafir Ahli Kitab. ${ }^{18}$

Paramadina sepakat bahwa dasar kepercayaan Ahli Kitab adalah perbuatan syirik (Q.S. al-Mâidah [5]: 17, 73; dan al-Tawbah [9]: 30). Namun demikian, al-Qur'ân tidak menyebut mereka sebagai musyrik. Berdasarkan ayat-ayat di atas, Paramadina menyimpulkan bahwa perbuatan syirik tidak menjadikan pelakunya disebut musyrik, terbukti sekalipun Yahudi dan Nasrani berbuat syirik, al-Qur'ân menyebut mereka Ahli Kitab (Q.S. al-Nisâ' [4]: 171; al-Mâidah [5]: 5; dan Al 'Imrân [3]: 64). ${ }^{19}$

Kesimpulan ini menurut Quraish Shihab sejalan dengan hasil pengamatan para pakar al-Qur'ân yang mengatakan bahwa istilah musyrik digunakan al-Qur'ân untuk menyebut para penyembah berhala yang ketika turunnya al-Qur'ân cukup banyak, khususnya yang menetap di Mekkah. Al-Qur'ân jelas membedakan istilah Ahli Kitab dan musyrik sekalipun keduanya sama-sama kafir, sebagaimana

\footnotetext{
15 Fakhr al-Dîn al-Râzî, Mafâtị̣ al-Ghayb, Vol. 6 (Beirut: Dâr Ihyyâ' al-Turâth al'Arabî, t.th.), 406.

${ }^{16}$ Sirry (ed.), Fiqh Lintas Agama, 155-156.

${ }^{17}$ Ibid., 156-157.

18 Ibid.

${ }^{19}$ Ibid., 158.
} 
istilah korupsi dan mencuri, sekalipun substansinya sama-sama mencuri, namun penggunaannya berbeda. ${ }^{20}$

Dalam rangka memperkuat kesimpulannya, Paramadina mengatakan dalam keseharian, umat Islam pun sering melakukan perbuatan syirik. Mempertuhankan hawa nafsu, harta, kedudukan, dan sebagainya adalah perbuatan syirik (Q.S. al-Nisâ' [4]: 36; alJâthiyah [45]: 23), ${ }^{21}$ namun mereka tidak disebut musyrik. Jika disebut musyrik, umat Islam tidak boleh menikahi mereka, bahkan yang sudah menikah pun, batal dengan sendirinya dan wajib cerai. Faktanya hal tersebut tidak pernah diterima. ${ }^{22}$

Wahbah al-Zuhaylî sepakat bahwa Ahli Kitab berbeda dengan musyrik. Menurutnya, Musyrik adalah kaum yang tidak menganut agama samawi, atau menyembah benda-benda tertentu seperti berhala, bintang, api, dan lain-lain. Sementara Ahli Kitab adalah kaum yang menganut agama samawi dan percaya kepada kitab suci tertentu. Termasuk kategori musyrik adalah kaum ateis. ${ }^{23}$

Pendapat ini dibantah oleh al-Râzî. Ia berusaha mematahkan argumen di atas, dengan mengajukan Q.S. al-Aḥzâb [33]: 7 dan alBaqarah [2]: 98:

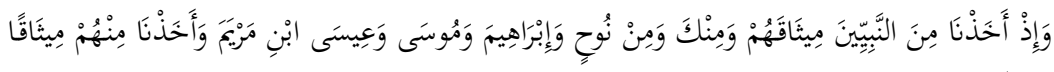

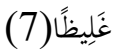

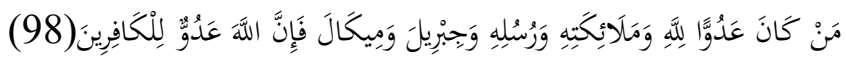

Dalam Q.S. al-Aḥâb [33]: 7, Allah memisahkan istilah para nabi, yakni Muhammad, Nuh, Ibrahim, Musa, dan 'Isa dengan menggunakan kata pemisah wâw, sekalipun mereka semua adalah nabi. Pada Q.S. al-Baqarah [2]: 98, Allah juga memisahkan istilah malaikat, Jibril, dan Mika'il dengan menggunakan kata pemisah wâw sekalipun mereka semua adalah malaikat. Jika dikatakan bahwa penyebutan secara khusus tersebut untuk menunjukkan tingkat kesempurnaan derajat yang dimaksud, maka penyebutan para penyembah berhala dalam beberapa ayat di atas secara khusus juga untuk menunjukkan derajat kekafiran mereka. ${ }^{24}$

\footnotetext{
20 Shihab, Tafsir al-Mishbah, Vol. 1, 473-474.

${ }^{21}$ Sirry (ed.), Fiqh Lintas Agama, 158-159.

${ }^{22}$ Ibid.

23 al-Zuhaylî, al-Fiqh al-Islâmî, Vol. 9, 6651.

24 al-Râzî, Mafâtị̣ al-Ghayb, Vol. 6, 406.
} 
Secara bahasa, Ahli Kitab berarti "yang mempunyai Kitab". Menurut Paramadina, istilah Ahli Kitab adalah konsep yang memberi pengakuan tertentu kepada para penganut agama di luar Islam yang memiliki kitab suci. Sikap ini bermaksud memberi pengakuan sebatas hak masing-masing untuk bereksistensi dengan kebebasan menjalankan agama, bukan memandang semua agama sama. ${ }^{25}$ Oleh sebab itu, istilah Ahli Kitab tidak tertuju kepada Muslim, sekalipun memiliki kitab suci. Ahli Kitab tidak tergolong Muslim karena mereka tidak percaya bahkan menentang Nabi Muhammad. ${ }^{26}$

Lebih jauh, Paramadina mengatakan bahwa istilah Ahli Kitab tidak mesti hanya dirujukkan kepada Yahudi dan Nasrani saja. Sebagaimana diketahui, Allah mengutus Rasul kepada setiap umat yang disertai dengan kitab suci dan Ajaran Keadilan (al-Mîzân) agar mereka bertindak dengan keadilan (Q.S. al-Hadîd [57]: 25). Untuk memperkuat argumennya, Paramadina mengutip pendapat Rashîd Rị̂â yang secara tegas mengatakan bahwa Ahli Kitab tidak hanya terbatas Yahudi dan Nasrani. Majusi, Sâbi'în, Hindu, Buddha, serta Konghucu dan lain-lain juga termasuk kelompok Ahli Kitab. AlQur'ân tidak menyebut Hindu, Buddha, dan Konghucu karena masyarakat Arab saat itu tidak mengenalnya. ${ }^{27}$ Menurut Riḍ̂, agamaagama semacam Hindu, Buddha, Konghucu, dan lain-lain pada dasarnya mengajarkan tauhid. Hanya saja dengan berlalunya waktu dan semakin jauhnya jarak dengan Nabi mereka, maka terjadi perubahan-perubahan atas ajaran kitab mereka. Atas dasar hal itu, ia memastikan bahwa mereka termasuk Ahli Kitab. ${ }^{28}$

Pendapat ini tidak jauh berbeda dengan pendapat Hanafîyah dan salah satu pendapat kelompok Hanâbilah. Menurut mereka, Ahli Kitab adalah setiap penganut agama samawi yang memiliki kitab suci seperti suhuf Ibrâhîm dan Shîth, Zabûr, dan lain-lain. Oleh sebab itu, boleh menikahi wanita mereka sepanjang tidak syirik. ${ }^{29}$

Pendapat ini dibantah oleh Shâfîîyah dan salah satu pendapat kelompok Hanâbilah. Menurut kelompok ini, Ahli Kitab hanya

\footnotetext{
${ }^{25}$ Sirry (ed.), Figh Lintas Agama, 43.

${ }^{26}$ Ibid., 45.

27 Ibid., 51-52. Lihat juga Muhammad Rashîd Riḍ̂a, Tafsîr al-Mannâr, Vol. 6 (Kairo: al-Hay'ah al-Mișriyah al-'Âmmah li al-Kitâb, 1990), 154 dan 156.

${ }^{28}$ Ibid., 185 dan 193.

${ }^{29}$ Sayyid Sâbiq, Fiqh al-Sunnah, Vol. 2 (Beirut: Dâr al-Fikr, 2008), 506.
} 
terbatas Yahudi dan Nasrani. ${ }^{30}$ Di antara alasan kelompok ini adalah, kitab-kitab selain Taurat dan Injil hanya berisi nasihat dan perumpamaan-perumpamaan dan tidak memuat hukum, sehingga tidak dapat disamakan dengan kitab-kitab yang memuat hukum. ${ }^{31} \mathrm{Di}$ samping itu, kitab-kitab itu bukan Kalam Allah melainkan wahyu dariNya sebagaimana hadîth. ${ }^{32}$

Wahbah al-Zuhaylî memperkuat pendapat ini. Menurutnya, Ahli Kitab yang dimaksud oleh al-Qur'ân adalah mereka yang mempercayai kitab suci Taurat dan Injil, bukan kitab suci-kitab suci sebelumnya, ${ }^{33}$ sejalan dengan pernyataan Q.S. al-An'âm [6]: 156 yang menyatakan bahwasanya Ahli Kitab adalah dua golongan saja. Hampir seluruh kitab tafsir sepakat bahwa dua kelompok yang dimaksudkan ayat di atas adalah Yahudi dan Nasrani. ${ }^{34}$

Sebagaimana al-Zuhaylî, Ibn 'Âshûr juga mengatakan bahwa Ahli Kitab adalah penganut kitab Taurat dan Injil, sekalipun mereka bukan dari kalangan Bani Israil. ${ }^{35}$ Quraish Shihab juga cenderung memahami Ahli Kitab terbatas pada Yahudi dan Nasrani, kapan pun, di mana pun, dan dari keturunan apa pun, berdasar ayat di atas. ${ }^{36}$

Paramadina memperkuat pandangannya dengan argumen lain. Menurutnya, sekalipun al-Qur'ân menyebut Yahudi dan Nasrani secara tegas sebagai Ahli Kitab, namun al-Qur'ân juga menyebut beberapa kelompok agama lain, yakni Majusi dan Șâbiîn yang dalam konteksnya mengesankan tergolong Ahli Kitab (Q.S. al-Hajj [22]: 17; al-Baqarah [2]: 62). Nabi sendiri memungut jizyah dari Majusi Bahrain dan Persia, bahkan Majusi Hajar. Oleh karena itu, banyak ulama menyimpulkan adanya Ahli Kitab di luar Yahudi dan Nasrani, sebab jizyah hanya dibenarkan dipungut dari Ahli Kitab yang hidup damai di negeri Muslim dan tidak boleh dipungut dari musyrik yang umat Islam tidak boleh berdamai dengan mereka. ${ }^{37}$

\footnotetext{
30 al-Râzî, Mafâtị al-Ghayb, Vol. 6, 120-124.

31 Ibid.

32 Abû Ishâa Ibrâhîm b. 'Alî b. Yûsuf al-Shîrâzî, al-Muhadhdhab fî̀ Fiqh al-Imâm alShâfi î́, Vol. 2 (Beirut: Dâr al-Fikr, 1994), 62.

33 al-Zuhaylî, al-Fiqh al-Islâmî, Vol. 9, 6613-6614.

34 al-Ṭabarî, Jâmi al-Bayân, Vol. 12, 240.

35 Muhammad al-Ṭ̂hir b. 'Âshûr, Tafsîr al-Taḥ̂ir wa al-Tanwîr, Vol. 8 (Tunis: al-Dâr al-Tûnisîyah li al-Nashr, 1984), 180.

${ }^{36}$ M. Quraish Shihab, Wawasan al-Qur'an: Tafsir Tematik atas Pelbagai Persoalan Umat (Bandung: Mizan, 1998), 368.

${ }^{37}$ Sirry (ed.), Fiqih Lintas Agama, 49.
} 
Paramadina mengutip riwayat hadîth dari Mâlik dan Shâfîî yang diriwayatkan 'Abd al-Raḥmân b. 'Awf: "sungguh aku mendengar Nabi bersabda: jalankanlah sunnahku kepada mereka seperti kepada Ahli Kitab. Namun ada keterputusan sanad dalam hadîth itu, meskipun digunakan sebagai bukti bahwa Majusi tidak termasuk Ahli Kitab. Oleh sebab itu, pandangan ini dinilai lemah oleh Paramadina. Menurut Paramadina, jika al-Qur'ân menggunakan istilah Ahli Kitab kepada Yahudi dan Nasrani, hal itu dikarenakan adanya kepastian asal usul kitab mereka dan tambahan sifat-sifat khusus mereka, namun tidak mesti berarti bahwa di dunia ini tidak ada Ahli Kitab selain mereka. ${ }^{38}$

Pernyataan Paramadina di atas, justru dapat melahirkan kesimpulan sebaliknya. Sangat mungkin dengan alasan adanya kepastian asal usul kitab mereka dan tambahan sifat-sifat khusus itulah al-Qur'ân menyebut Ahli Kitab hanya sebatas Yahudi dan Nasrani. Jika istilah Musyrik terbatas pada Musyrik Arab, bukankah sangat masuk akal pula jika istilah Ahli Kitab juga terbatas pada Yahudi dan Nasrani?.

Nabi sendiri menjelaskan bahwa suhuf Ibrahim 'hanya' berisi perumpamaan-perumpamaan (kânat amthâlan kullahâ, sementara suhuf Musa hanya berisi nasihat-nasihat. ${ }^{39}$ Imam Shâfíî menyatakan bahwa kitab-kitab samawi selain Taurat, Injil dan al-Qur'ân bukan Kalam Allah, melainkan semacam hadîth. ${ }^{40}$ Dengan penjelasan itu, dapat disimpulkan bahwa kitab suci Yahudi dan Nasrani memang berbeda dengan kitab-kitab samawi yang lain, sehingga kitab-kitab samawi yang lain tidak dapat dipersamakan dengan Taurat dan Injil. Oleh sebab itu, sangat wajar penganutnya juga tidak disebut dengan istilah yang sama. Di samping itu, bukankah tidak semua penganut agama samawi disebut Ahli Kitab, sebagaimana umat Islam yang juga tidak disebut Ahli Kitab? Bukankah al-Qur'ân sangat teliti dalam redaksiredaksinya sehingga tidak ada peluang untuk terjadinya kerancuan dalam menggunakan istilah (11 $^{41}$

\footnotetext{
${ }^{38}$ Ibid., 50. Lihat juga Riḍâ, al-Mannâr, Vol. 6, 156.

39 Mụ̣y al-Dîn b. Aḥmad Muṣtafâ Darwish, I'râb al-Qur'ân wa Bayânuh, Vol. 10 (Beirut: Dâr al-Irshâd, 1415), 454.

40 'Abd Rạ̣mân b. Muhammad al-Qummâsh, al-Hâwî fî Tafsîr al-Qur'ân al-Karîm (t.t.: t.p., 2009), 812.

${ }^{41}$ Shihab, al-Mishbah, 370.
} 


\section{Hukum Pernikahan Muslim dengan Musyrik dan Ahli Kitab}

\section{A. Pernikahan Lelaki Muslim dengan Wanita Musyrik dan Ahli Kitab}

Secara umum, dasar hukum keharaman pernikahan dengan nonMuslim adalah Q.S. al-Baqarah [2]: 221 dan Q.S. al-Mumtahanah [60]: $10 . .^{42}$

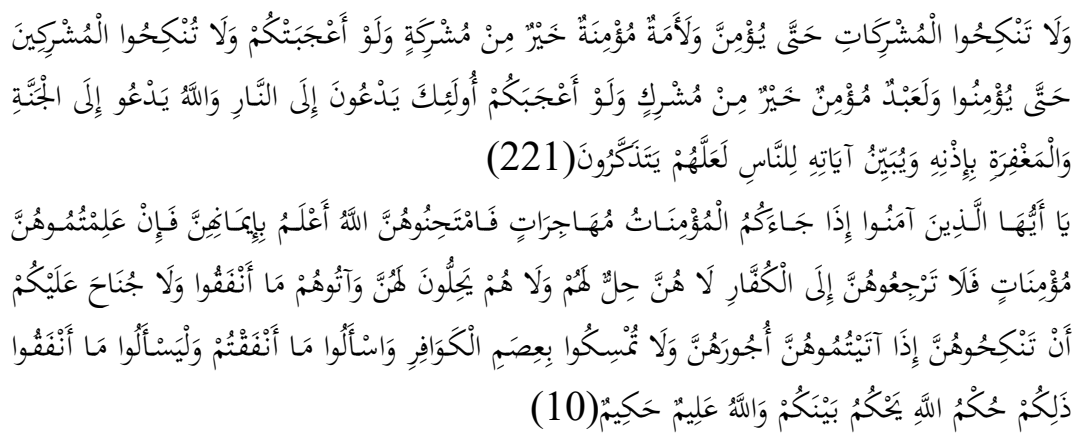

Dalam memahami ayat di atas, ulama terbagi menjadi dua kelompok. Kelompok pertama berpendapat bahwa pria Muslim tidak boleh menikahi wanita Musyrik, termasuk wanita Ahli Kitab. Namun demikian, mereka berbeda pendapat dalam mengemukakan alasan keharaman pernikahan tersebut. Sebagian berpendapat bahwa lafal almushrikin dan al-mushrikât dalam ayat Q.S. al-Baqarah [2]: 221 di atas adalah umum meliputi seluruh Musyrik termasuk Ahli Kitab, karena akidah mereka syirik ${ }^{43}$ sebagaimana disebutkan dalam Q.S. al-Tawbah [9]: 31 dan al-Fath [48]: 4. Berdasarkan keumuman lafal tersebut, seluruh kelompok musyrik haram dinikahi, termasuk wanita Ahli Kitab. Q.S. al-Baqarah [2]: 221 ini sekaligus me-naskh ayat yang memperbolehkan pernikahan dengan wanita Ahli Kitab dalam Q.S. alMâidah [5]: 5, ${ }^{44}$ yakni:

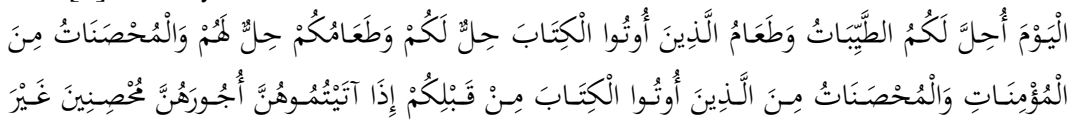

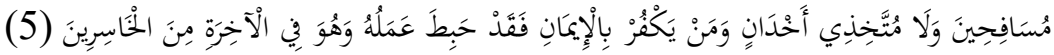

Logika naskh ini dibantah oleh Riḍâ karena dinilai tidak masuk akal, sebab al-Mâidah adalah surat terakhir yang turun sehingga tidak

\footnotetext{
42 Riḍ̂, al-Mannâr, Vol. 2, 276.

43 Ibid., 278.

${ }^{44}$ Ibid., 277-278.
} 
logis jika yang turun belakangan di-naskh oleh yang turun lebih dulu. ${ }^{45}$ Ibn 'Abbâs dan al-Awzâ'i juga menyatakan bahwa tidak ada ayat yang mansûkh dalam surat al-Mâidah. ${ }^{46}$

Ulama lain dari kelompok ini, di antaranya Ibn 'Umar, melakukan takwil bahwa al-Mâidah tersebut di-taqyîd bagi mereka yang masuk Islam. Ayat ini turun untuk menjawab keraguan sebagian Muslim, apakah Yahudi yang telah masuk Islam dapat dinikahi atau tidak. Takwil ini juga dinilai tidak beralasan, karena jika sudah menjadi Muslim, otomatis mereka halal dinikahi. ${ }^{47}$

Berbeda dengan pandangan di atas, kelompok kedua yakni jumhur ulama berpendapat bahwa laki-laki Muslim boleh menikahi wanita Ahli Kitab. Sebagaimana kelompok pertama, mereka juga berbeda dalam mengemukakan argumen kebolehan tersebut. Pertama, sebagian berpendapat bahwa kebolehan menikahi wanita Ahli Kitab berdasarkan Q.S. al-Mâidah [5]: 5. Menurut pandangan kelompok ini kemumuman lafal al-mushrikîn dan al-mushrikât dalam Q.S. al-Baqarah [2]: 221 di-takhsı̂s.s oleh Q.S. al-Mâidah [5]: 5. Berdasarkan takhsı̂s.s tersebut, maka laki-laki Muslim boleh menikahi wanita Ahli Kitab. Pendapat ini mengacu kepada riwayat dari Ibn 'Abbâs, Mujâhid, 'Ikrimah, Sa î̀ b. Jubair, al-Ḥasan, al-Ḍaḥhâk, dan lain-lain. ${ }^{48}$ Sebagian berpendapat bahwa Q.S. al-Baqarah [2]: 221 tidak di-takhsîs, melainkan di-naskh oleh Q.S. al-Mâidah [5]: 5. Pendapat ini mengacu kepada salah satu riwayat 'Ikrimah, Ḥasan al-Bașî̀, dan Mujâhid." Kelompok ini dengan demikian berpendapat bahwa Ahli Kitab termasuk musyrik.

Al-Kayyâ al-Harasî menolak logika naskh ini. Menurutnya, Q.S. alBaqarah [2]: 221 berbentuk umum, sementara Q.S. al-Mâidah [5]: 5 berbentuk khusus. Dengan demikian, tidak ada kontradiksi antara dua dalil tersebut, sehingga tidak perlu naskh kontradiksitidak dapat terjadi

\footnotetext{
45 Ibid., 278.

46 Wahbah al-Zuhaylî, al-Tafsîr al-Munîr fì al-'Aqîdah, wa al-Sharî́ah wa al-Manhaj, Vol. 2 (Damaskus: Dâr al-Fikr, 1418), 290.

47 Muhammad b. Aḥmad b. Abî Sahl Shams al-Aimmah al-Sarakhsî, al-Mabsût, Vol. 34 (t.t.: t.p., t.th.), 177. Al-Râzî, Mafâtị̣ al-Ghayb, Vol. 11, 294. Lihat juga Riḍ̂, Tafsîr al-Mannâr, Vol. 2, 278.

48 Sirry (ed.), Fiqih Lintas Agama, 162-163.

49 al-Ṭabarî, Jâmi' al-Bayân, Vol. 3, 711.
} 
antara dalil yang muḅtamal (multitafsir) dengan dalil yang tidak mubtamal..$^{50}$

Kedua, sebagian berpendapat bahwa Q.S. al-Baqarah [2]: 221 tersebut tidak mansûkh ataupun di-takhșîs oleh Q.S. al-Mâidah [5]: 5. Dua ayat tersebut memang memuat dua hukum berbeda. Q.S. alBaqarah [2]: 221 menunjukkan keharaman menikahi musyrik, sementara Q.S. al-Mâidah [5]: 5 menunjukkan kebolehan menikahi wanita Ahli Kitab. ${ }^{51}$ Dengan demikian, dalam pandangan kelompok ini Ahli Kitab tidak termasuk musyrik.

Sekalipun memperbolehkan pernikahan dengan Ahli Kitab, kelompok ini berbeda pendapat, apakah Ahli Kitab tersebut mereka yang berpegang pada Taurat dan Injil versi aslinya sebelum terjadi perubahan, ataukah termasuk mereka yang beriman kepada kedua kitab suci tersebut sebelum atau setelah terjadi perubahan seperti Bani Israil dari kalangan Yahudi?. ${ }^{2}$

Al-Shâfi'î menurut riwayat al-Rabî’ menyatakan bahwa Ahli Kitab adalah penganut Taurat dan Injil sebelum diutusnya Nabi Muhammad. Pasca-diutusnya Nabi Muhammad, maka hukum mereka sebagaimana musyrik..$^{53}$ Alasan kelompok ini adalah dalam Q.S. alMâidah [5]: 5, kebolehan menikahi Ahli Kitab dibatasi oleh lafal min qablikum. ${ }^{54}$ Dalam kesimpulan Ibrahim Hosen-mantan rektor IIQ Jakarta-pengakuan Shâfi îyah terhadap pernikahan dengan Ahli Kitab semata-mata karena menghormati keturunannya, bukan karena mengakui kebenaran agamanya. ${ }^{55}$

Pendapat ini dibantah oleh Riḍâ. Menurutnya, al-Qur'ân, alsunnah, serta praktik di kalangan sahabat menunjukkan bahwa alQur'ân memperbolehkan menikahi wanita Ahli Kitab sesuai dengan keberadaan mereka saat turunnya al-Qur'ân. Al-Qur'ân sendiri dan

\footnotetext{
50 al-Kayyâ al-Harasî, Aḥkâm al-Qur'ân, Vol. 1 (Beirut: Dâr al-Kutub al-'Ilmîyah, 1405), 129.

51 Abû al-Fidâ' Ismâ'îl b. 'Umar b. Kathîr, Tafsîr al-Qur'ân al-'Ažîm, Vol. 1 (t.t.: Dâr Taybah li al-Nashr wa al-Tawzî‘, 1999), 582. Lihat juga al-Zuhaylî, al-Tafsir al-Munîr, Vol. 2, 293.

52 Riḍ̂, al-Manar, Vol. 6, 148.

53 al-Râzî, Mafâtị̣ al-Ghayb, Vol. 6, 120-124.

54 al-Zuhaylî, al-Figh al-Islâmî, Vol. 9, 6613-6614.

55 Ibrahim Hosen, "Perkawinan Antar Agama menurut Hukum Islam", dalam Dadang Hawari dkk, Persiapan menuju Perkawinan yang Lestari (Jakarta: Pustaka Antara, 1993), 69.
} 
pada surat ini (al-Mâidah) menjelaskan bahwa mereka melakukan perubahan-perubahan terhadap kitab suci mereka. ${ }^{56}$

Sebuah analisis menarik dikemukakan oleh Ibrahim Hosen. Menurutnya, kelemahan pendapat yang menghalalkan pernikahan Muslim dengan wanita Ahli Kitab adalah ketika seorang Muslim menikah dengan Muslimah, secara otomatis pernikahan itu dianggap fasakh jika istrinya yang Muslimah menjadi Yahudi atau Nasrani. ${ }^{57}$

Sebagaimana disebutkan di atas, dalam kesimpulan Paramadina, musyrik dan Ahli Kitab adalah dua kelompok yang berbeda. Oleh sebab itu, ketika al-Qur'ân (al-Baqarah [2]: 221) mengharamkan menikahi perempuan musyrik, menurut Paramadina tidaklah tepat jika dipahami sebagai pengharaman tehadap perempuan Ahli Kitab. Paramadina juga mengutip pendapat Muhammad 'Abduh yang secara spesifik berpendapat bahwa perempuan yang haram dinikahi oleh laki-laki Muslim dalam surat al-Baqarah [2]: 221 itu adalah musyrik Arab. Pertanyaannya, apakah saat ini masih terdapat orang-orang seperti musyrik Arab? Jika masih ada, maka hukum berlaku. Jika tidak, maka tidak ada satu pun kepercayaan dan agama yang menjadi kendala dalam melakukan pernikahan. ${ }^{58}$

Pendapat bahwa yang dimaksud musyrik dalam Q.S. al-Baqarah [2]: 221 itu adalah musyrik Arab, jauh sebelumnya sudah dikemukakan oleh Qatâdah. Menurutnya, ayat ini ditujukan kepada musyrik Arab di mana mereka tidak memiliki kitab suci. Ayat ini zahirnya bersifat umum, namun batin maknanya khusus, tidak mansûkh, dan tidak mencakup wanita Ahli Kitab, karena kehalalan menikahi wanita Ahli Kitab dijelaskan dalam Q.S. al-Mâidah [5]: $5 .{ }^{59}$

Lebih lanjut Paramadina mengatakan bahwa Q.S. al-Mâidah [5]: 5 ini merupakan alasan yang cukup fundamental dibolehkannya pernikahan dengan non-Muslim. ${ }^{60}$ Paramadina menyebut Q.S. alMâidah [5]: 5 sebagai "ayat revolusi”, karena secara eksplisit menjawab keraguan masyarakat Muslim saat itu tentang hukum pernikahan dengan non-Muslim. Ayat ini membuka ruang bagi wanita Kristen dan Yahudi untuk melakukan pernikahan dengan seorang Muslim. ${ }^{61}$

\footnotetext{
${ }^{56}$ Riḍ̂, al-Mannâr, Vol. 6, 149.

${ }^{57}$ Hosen, "Perkawinan Antar Agama", 70.

58 Sirry (ed.), Fiqih Lintas Agama, 160.

${ }^{59}$ al-Ṭabarî, Jâmi‘ al-Bayân, Vol. 4, 363-365.

${ }^{60}$ Sirry (ed.), Fiqih Lintas Agama, 162.

61 Ibid., 162-163.
} 
Dalam pandangan Paramadina, Q.S. al-Mâidah [5]: 5 bisa berfungsi dua hal sekaligus, yaitu penghapus (nâsikh) dan pengkhusus (mukhassiss) dari ayat sebelumnya yang melarang pernikahan dengan orang musyrik. Dalam kaidah fiqh disebutkan jika terdapat dua ayat bertentangan, maka diambil ayat yang turun belakangan. ${ }^{62}$

Dengan pernyataan di atas, cukup sulit memahami logika yang digunakan Paramadina, karena ada ambivalensi dalam mengemukakan argumennya. Di satu sisi mereka mengatakan bahwa Ahli Kitab bukan musyrik, karena itu Q.S. al-Baqarah [2]: 221 hanya berbicara tentang keharaman menikahi wanita musyrik, yakni Musyrik Arab. Namun di sisi lain mereka menyatakan bahwa Q.S. al-Mâidah [5]: 5 bisa berfungsi dua hal sekaligus, yaitu penghapus (nâsikh) dan pengkhusus (mukhassisis) dari ayat sebelumnya yang melarang pernikahan dengan musyrik.

Jika berfungsi sebagai mukhașsis atau nâsikh, berarti Paramadina berpendapat bahwa Ahli Kitab juga Musyrik. Dalam kaidah usul fiqh, naskh hanya dapat dilakukan jika terdapat dua ayat bertentangan yang tidak mungkin dikompromikan, di mana dua ayat tersebut berbicara tentang objek yang sama, konteks sama, persoalan yang sama, illat yang sama, sasaran yang sama, namun menentukan hukum berbeda. ${ }^{63}$ Jika Paramadina menganggap bahwa Q.S. al-Mâidah [5]: 5 me-naskh Q.S. al-Baqarah [2]: 221, berarti mereka menganggap bahwa Ahli Kitab adalah bagian dari Musyrik.

Takhsîs juga hanya dilakukan jika terdapat dua dalil yang berbicara objek yang sama namun yang satu berbentuk umum, sementara yang lain berbentuk khusus di mana keduanya memuat hukum yang berbeda. ${ }^{64}$ Jika Paramadina menilai bahwa Q.S. al-Mâidah [5]: 5 mentakhsîs.s Q.S. al-Baqarah [2]: 221, berarti mereka menganggap bahwa Ahli Kitab adalah bagian dari musyrik.

Di samping alasan di atas, Paramadina juga mengemukakan sejumlah argumen lain. Pertama, larangan menikahi musyrik, pada dasarnya karena dikhawatirkan wanita musyrik atau laki-laki musyrik memerangi orang-orang Islam. Ayat ini menurut catatan Paramadina turun dalam situasi di mana terjadi ketegangan antara orang Islam

\footnotetext{
62 Ibid.

63 'Abd al-Ḥamîd Hakîm, al-Bayân, Vol. 3 (Jakarta: Maktabah al-Sa'diyah Putra, t.th.), 182-183.

${ }^{64}$ Wahbah al-Zuhaylî, U.sûl al-Figh al-Islâmî, Vol. 1 (Beirut: Dâr al-Fikr al-Mu'âṣir, 2001), 254.
} 
dengan musyrik Arab. Dengan demikian menjadi jelas bahwa yang dimaksud musyrik dalam Q.S. al-Baqarah [2]: 221 adalah mereka yang suka memerangi umat Islam. ${ }^{65}$

Dengan demikian, Paramadina menilai bahwa illat pengharaman tersebut adalah "permusuhan". Berdasarkan kaidah bahwa hukum tergantung pada 'illat (al-hukm yadûr ma'a 'illatih wujûdan wa 'adaman), berarti tidak semua musyrik haram dinikahi. Musyrik Arab pun-jika masih ada-boleh dinikahi sepanjang tidak memusuhi umat Islam. Sebaliknya, Ahli Kitab pun jika memusuhi umat Islam juga haram dinikahi.

Berbeda dengan Paramadina, beberapa mufassir di antaranya alṬabarî dan al-Zuhaylî berpendapat bahwa 'illat keharaman menikahi musyrik adalah karena mereka mengajak ke neraka (ann al-illah fî̀ tạ̣rîm nikahibinn al-du'â' ilâ al-nâr). ${ }^{66}$ Konsekuensinya, jika mereka tidak membawa ke neraka, maka boleh dinikahi.

Kedua, dalam masyarakat Arab, terdapat tiga kelompok masyarakat yang disebut sebagai kelompok lain (al-âkhar), yaitu musyrik, Kristen, dan Yahudi. Musyrik adalah mereka yang memiliki kedudukan tinggi dan penting di tengah masyarakat dan berpusat di Mekkah. Mereka memiliki patung besar berbentuk manusia yang terbuat dari akik dan menghadap Ka'bah yang disebut "Hibal". Patung tersebut dikelilingi patung-patung kecil sebanyak 360 buah. ${ }^{67}$

Sementara itu Kristen merupakan kekuatan yang sangat besar di dataran Arab. Mereka berasal dari Syam yang melarikan diri ke Arab karena menghindari kezaliman penguasa Romawi. Mereka menempati puncak-puncak gunung dan bukit melalui pedagang Afrika. Sejumlah kabilah Arab antara lain Ghassan, Taghallub, Tanukh, Lakhm, Kharam, dan lain-lain akhirnya memeluk Kristen. Kaum Yahudi juga merupakan pelarian dari Syam akibat kezaliman Persia dan Romawi. Berbeda dengan kaum musyrik yang berpusat di Mekkah, pusat mereka di Madinah dan merupakan separuh dari seluruh penduduk Madinah. Di antara kabilah Yahudi adalah Qaynuqâ', Nazîr, dan Qurayẓah. ${ }^{68}$

\footnotetext{
${ }^{65}$ Sirry (ed.), Fiqih Lintas Agama, 160-161.

${ }^{66}$ al-Ṭabarî, Jâmi' al-Bayân, Vol. 3, 716. Lihat juga al-Zuhaylî, Tafsîr al-Munîr, Vol. 2, 292.

${ }^{67}$ Sirry (ed.), Fiqih Lintas Agama, 161.

${ }^{68}$ Ibid.
} 
Komposisi masyarakat seperti itu menunjukkan ada distingsi yang jelas antara musyrik, Yahudi, dan Kristen. Perbedaan musyrik dengan Yahudi dan Kristen terletak pada ajaran monoteisme. Musyrik sepertinya merupakan sebuah kekuatan politik murni yang ambisinya adalah kekuasaan dan kekayaan, sedangkan Yahudi dan Kristen memiliki persinggungan teologis dengan Islam. Sekalipun terdapat ketegangan dengan komunitas Muslim, setidaknya terdapat upaya bersama untuk membangun kesepahaman dengan diterbitkannya Piagam Madinah yang merupakan kesepakatan kelompok Muslim, Yahudi, dan Kristen. Bahkan ketiganya sepakat untuk menjadi umat yang satu (ummah wâhịidah). Dalam beberapa ayat, al-Qur'ân pun secara eksplisit menyatakan bahwa kaum Yahudi, Nasrani, dan kaum Ṣâbi'ah serta mereka yang beramal saleh, akan mendapat imbalan yang setimpal di hari kiamat (Q.S. al-Baqarah [2]: 62). ${ }^{69}$

Paramadina juga menunjukkan beberapa sahabat Nabi yang menikahi wanita Kristen dan Yahudi, di antaranya Hudhayfah dan Ṭalhah. Khalifah 'Umar memang sempat marah atas pernikahan tersebut, namun bukan karena menganggap bahwa pernikahan itu haram, melainkan diduga karena khawatir sahabat masuk dalam komunitas non-Muslim, sementara saat itu umat Islam masih membutuhkan jumlah pengikut yang banyak dan setia. Apalagi dua sahabat tersebut merupakan tokoh menonjol sehingga wajar jika Khalifah mengingatkan. Oleh sebab itu, ketika al-Qur'ân mengharamkan menikahi perempuan musyrik, tidaklah tepat jika dipahami sebagai pengharaman terhadap perempuan Ahli Kitab. ${ }^{70}$

Pernyataan 'Umar menunjukkan bahwa menikahi wanita Ahli Kitab memang diperbolehkan. Larangan yang dikeluarkannya dengan demikian berdasarkan sadd al-dharíah. ${ }^{71}$ Dalam pandangan banyak ulama, para ulama salaf menikahi wanita Ahli Kitab karena mereka mampu menuntun istrinya ke dalam Islam. Kalau kita melihat sekarang, pernikahan sesama Muslim pun sering melahirkan hal-hal tidak baik, bagaimana jika menikah dengan non-Muslim? ${ }^{72}$

\footnotetext{
${ }^{69}$ Ibid.

70 Ibid., 162.

${ }^{71}$ Tim Majallah, Mujamma' al-Fiqh al-Islâmî al-Tabi' li Munażzamat al-Mu'tamar al-Islâmî bi Jiddah, 9, 1319 dan 1653.

${ }^{72}$ Husayn b. 'Awdah al-'Awayîsah, al-Mawsû'ah al-Fiqhîyah al-Muyassarah fì Fiqh alKitâb wa al-Sunnah al-Mutahharah, Vol. 5 (Beirut: al-Maktabah al-Islâmîyah Dâr Ibn Hazm, 1429), 107.
} 


\section{Hukum Pernikahan Wanita Muslimah dengan Laki-Laki Musyrik dan Ahli Kitab}

Berbeda dengan pernikahan laki-laki Muslim dengan perempuan non-Muslim, pernikahan wanita Muslimah dengan laki-laki nonMuslim (Ahli Kitab), tidak ditemukan teks agama baik al-Qur'ân, hadîth, ataupun fiqh yang memperbolehkannya. Menariknya, menurut Paramadina tidak ditemukan juga nașs yang secara sarî̉ melarang pernikahan tersebut. Hanya saja ada sebuah hadîth Nabi, yang tidak jelas kedudukannya, yang menyatakan, "kami menikahi wanita-wanita Ahli kitab, dan laki-laki Ahli Kitab tidak boleh menikahi wanitawanita kami" ${ }^{73}$

Setelah diteliti, hadîth tersebut dikomentari Ṣudqî Jamîl al-'Ațtâr sebagai hadîth yang tidak sahih. Hadîth tersebut merupakan hadîth mawqûf yang sanadnya terputus hingga Jâbir sebagaimana dijelaskan al-Shâfíi dalam al-Umm. Dengan demikian, menurut Paramadina dapat disimpulkan bahwa persoalan ini merupakan persoalan ijtihadi yang terikat dengan konteks dakwah Islam. ${ }^{74}$

Al-Ṭabarî dalam tafsirnya juga memberi catatan bahwa sanad hadîth itu "bermasalah". Ia mengemukakan dua riwayat serupa yang masing-masing dinisbatkan kepada Nabi dan sahabat 'Umar, yakni:

$$
\begin{aligned}
& \text { عن جابر بن عبد الله قال :قال رسول الله صلى الله عليه وسلم" :نتزوج نساء أهل الكتاب ولا لا لماءل } \\
& \text { يتزوجون نساءنا." }
\end{aligned}
$$

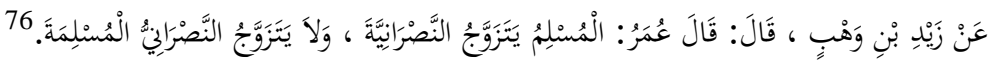

Sebagai sebuah persoalan ijtihadi, menurut Paramadina amat mungkin dicetuskan sebuah pendapat baru, bahwa wanita Muslimah boleh menikah dengan laki-laki non-Muslim apapun agama dan aliran kepercayaan yang dianutnya. Hal ini merujuk pada semangat yang dibawa al-Qur'ân. Pertama, pluralitas agama merupakan sunnatullah yang tidak bisa dihindarkan. Tuhan menyebut agama-agama samawi dan mereka membawa ajaran amal salih sebagai orang yang akan bersama-Nya di surga. Bahkan Tuhan menyebutkan perbedaan jenis kelamin dan suku dijadikan sebagai tanda agar satu sama lain saling

\footnotetext{
${ }^{73}$ Sirry (ed.), Fiqih Lintas Agama, 163-164.

${ }^{74}$ Ibid.

75 al-Ṭabarî, Jâmi al-Bayân, Vol. 4, 367. Hadîth ini juga diriwayatkan dalam Abû alṬayyib Muhammad Shams al-Haq Abâdî, 'Awn al-Ma'bûd: Sharb Sunan Abî Dâwud, Vol. 8 (Madinah: al-Maktabah al-Salafiyah, 1968), 12.

76 al-Ṭabarî, Jâmi‘ al-Bayân, Vol. 3, 716.
} 
mengenal. Pernikahan beda agama dapat dijadikan salah satu ruang antarpemeluk agama untuk saling mengenal. ${ }^{77}$

Kedua, tujuan pernikahan adalah untuk membangun tali kasih dan sayang. Di tengah rentannya hubungan antar agama saat ini, pernikahan beda agama justru dapat dijadikan wahana untuk membangun toleransi dan kesepahaman antar pemeluk agama. Bermula dari ikatan kasih sayang, selanjutnya dapat dirajut kedamaian dan kerukunan. ${ }^{78}$

Ketiga, semangat Islam adalah pembebasan, bukan belenggu. Tahapan yang dilakukan al-Qur'ân sejak larangan pernikahan dengan musyrik, lalu membuka jalan pernikahan dengan Ahli Kitab merupakan tahapan pembebasan secara evolutif. Pada saatnya harus dilihat agama lain bukan sebagai agama kelas dua dan bukan abl aldbimmah dalam arti menekan mereka, melainkan sebagai warga negara. Fahmî Huwaydî sudah memulai langkah tersebut dengan manifestonya bahwa non-Muslim adalah warga negara, bukan kelas kedua (muwâtinûn lâ dhimmiyûn). ${ }^{79}$

Berbeda dengan pandangan Paramadina, menurut Ibn 'Âshûr, sekalipun tidak ada naș yang berbicara tentang hukum pernikahan wanita Muslimah dengan laki-laki Ahli Kitab, namun para ulama melarangnya atas alasan bahwa nașs (al-Mâidah) hanya memperbolehkan pernikahan laki-laki Muslim dengan Ahli Kitab, atau berdasarkan hadîth Nabi, ijmấ, atau qiyas. ${ }^{80}$

Sebagian ulama Shâfiîyah berargumen, jika kebolehan menikahi wanita Ahli Kitab berdasarkan takbsîș Q.S. al-Mâidah [5]: 5 terhadap Q.S. al-Baqarah [2]: 221, berarti wanita Muslimah tidak boleh menikah dengan mereka karena mereka tidak termasuk bagian yang ditakhșị̂. Sayyid Sâbiq bahkan mengatakan telah terjadi ïmâ' di kalangan ulama bahwasanya wanita Muslimah tidak boleh menikah dengan lakilaki non-Muslim, baik dari kalangan musyrik maupun Ahli Kitab. Dasar keharaman tersebut adalah Q.S. al-Mumtahanah [60]: 10. Menurut Sayyid Sâbiq, pernyataan al-Qur'ân "mereka tidak halal bagi orang-orang kafir itu dan orang-orang kafir itu tidak halal bagi mereka" merupakan pernyataan yang sangat tegas tentang haramnya perempuan Muslimah menikahi laki-laki non-Muslim. ${ }^{81}$

\footnotetext{
${ }^{77}$ Sirry (ed.), Fiqih Lintas Agama, 164.

${ }^{78}$ Ibid.

${ }^{79}$ Ibid., 164-165.

${ }^{80}$ Ibn 'Âshûr, Tafsîr al-Tabrîr, 340.

81 Sâbiq, Fiqh al-Sunnah, Vol. 2, 506-507.
} 
Hikmah larangan tersebut adalah karena laki-laki memegang kepemimpinan dalam keluarga sehingga ia memegang kendali rumah tangga. Sebagai pemimpin, ia berhak dipatuhi, sementara sebagai kafir, ia tidak boleh memimpin Muslim, baik laki-laki maupun perempuan (Q.S. al-Nisâ' [4]: 141). Laki-laki kafir tidak beriman terhadap Nabi dan kitab suci umat Islam sehingga mustahil mereka dapat menghormati umat Islam. Sebaliknya laki-laki Muslim beriman kepada Nabi dan kitab suci mereka sehingga pasti menghormati agama mereka. ${ }^{82}$

Al-Zuhaylî sepakat bahwa telah terjadi ijmât atas keharaman wanita Muslimah menikah dengan laki-laki kafir, baik ia musyrik, maupun Ahli Kitab, berdasarkan Q.S. al-Baqarah [2]: 221 dan Q.S. alMumtahanah [60]: 10. Pada akhir ayat Q.S. al-Baqarah [2]: 221 disebutkan (ulâik yad'ûn ilâ al-nâr). Hal itu merupakan isyarat bahwa laki-laki sebagai kepala keluarga sangat potensial membawa istrinya mengikuti agama dan keyakinannya. Di samping itu, al-Qur'ân telah memotong kepemimpinan kafir atas muslim Q.S. al-Nisâ’ [4]: $141 .^{83}$

Rị̂â sepakat bahwa al-Mâidah [5]: 5 tidak memuat hukum pernikahan wanita Muslimah dengan Ahli Kitab. Sebagian ulama, termasuk 'Abduh berpendapat bahwa hal tersebut menunjukkan keharamannya yang juga diperkuat oleh sunnah dan ijmâ.84

\section{Menimbang Kemaslahatan Pernikahan Beda Agama}

Jika mencermati argumen Paramadina di atas, ijtihad Paramadina tentang pernikahan beda agama terlihat lebih banyak dibangun di atas pertimbangan muamalah, yakni terciptanya kerukunan antarumat beragama. Hal ini setidaknya dapat dilihat dari pernyataan Paramadina yang mengatakan "di tengah rentannya hubungan antaragama saat ini. Pernikahan beda agama justru dapat dijadikan wahana untuk membangun toleransi dan kesepahaman antarpemeluk agama". ${ }^{85}$

Argumen tersebut memang masuk akal. Pernikahan beda agama sangat mungkin melahirkan kerukunan antarumat beragama. Di tengah gencarnya permusuhan terhadap umat Islam sebagaimana ditunjukkan oleh beberapa kelompok akibat berbagai aksi kekerasan yang terjadi akhir-akhir ini, pernikahan bisa menjadi media untuk menumbuhkan rasa simpati antar pemeluk agama. Dengan demikian,

\footnotetext{
82 Ibid.

83 al-Zuhaylî, al-Fiqh al-Islâmî, Vol. 9, 6652.

${ }^{84}$ Riḍâ, Tafsîr al-Mannâr, Vol. 1, 279.

85 Sirry (ed.), Fiqih Lintas Agama, 164.
} 
kesimpulan Paramadina bahwa sikap permusuhan terhadap umat Islam menjadi 'illat diharamkannya pernikahan dengan musyrik dalam Q.S. al-Baqarah [2]: $221^{86}$ perlu ditinjau ulang. Kesimpulan ini jelas kontradiktif dengan analisis Paramadina sendiri yang menyatakan bahwa pernikahan bisa menjadi media terciptanya kerukunan. Bukankah untuk menciptakan kerukunan, semestinya yang memusuhi itulah yang harus dinikahi?

Di samping itu, sekalipun terjadinya kerukunan akibat pernikahan beda agama sangat mungkin terjadi. Di sisi lain sangat mungkin pula terjadi kerusakan akidah. Salah seorang ulama salaf, Imam 'Ațâ' termasuk ulama yang memiliki kekhawatiran tersebut. Dalam pernyataannya, ia mengatakan "rasa cinta yang mendalam, bisa jadi membuat suami (atau istri yang Muslim) justru mengikuti agama istrinya (atau suaminya yang non-Muslim)". ${ }^{87}$ Kekhawatiran senada juga disampaikan 'Alî al-Ṣâbûnî. Menurutnya, ikatan kasih sayang antar suami istri itu bisa menjadi sumber persoalan serius, sebab jika cinta itu sudah sedemikian kuat, sangat mungkin sang suami (atau istri) yang Muslim akan terpengaruh untuk mengikuti agama istrinya (atau suaminya yang non-Muslim). Jika demikian halnya, pernikahan ini harus dinyatakan haram secara pasti. ${ }^{88}$ Pertanyaannya adalah, bagaimana kalau yang terjadi adalah sebaliknya? Pernikahan itu mampu menarik pasangannya masuk Islam?

Perlindungan terhadap akidah tentu saja harus menjadi pertimbangan utama. Pertimbangan muamalah harus dikesampingkan jika dalam upaya mewujudkannya membahayakan akidah. Menghindari mafsadah dalam bentuk rusaknya akidah juga harus didahulukan daripada upaya menarik maslahah dalam bentuk menarik pasangan masuk Islam sesuai dengan kaidah dar' al-mafâsid muqaddma 'alâ jalb almanâfi : Terciptanya kerukunan antarumat beragama juga bisa berbalik menjadi permusuhan jika dalam perjalanannya, bangunan akidah umat banyak yang runtuh.

Mengharap pasangan berpindah agama setelah menjalani pernikahan nampaknya terlalu spekulatif, walaupun tetap mungkin terjadi. Kalaupun masing-masing pasangan tetap berpegang pada agamanya, persoalan yang tak kalah krusialnya adalah persoalan anak. Menurut penelitian Calvina dan Elvi Andriani Yusuf tentang

\footnotetext{
${ }^{86}$ Ibid., 160-161.

${ }^{87}$ al-Râzî, Mafâtị al-Ghayb, Vol. 11, 294.

88 al-Ṣâbûnî, Rawâ'i al-Bayân, Vol. 1, 248.
} 
"Konflik Pemilihan Agama Pada Remaja dari Perkawinan Beda Agama, anak yang lahir dari pernikahan beda agama mengalami situasi konflik, ketika mereka harus menentukan identitas agama mereka, apakah memilih agama ayah, ibu atau agama lainnya. ${ }^{89}$

Zainul Mu'ien Husni juga memiliki kesimpulan serupa. Sekalipun hanya melakukan pengamatan 'ala kadarnya' di lapangan, ia juga menilai bahwa pengaruh negatif pernikahan beda agama, besar dan masif, khususnya bagi mentalitas dan tingkat keberagamaan anak yang lahir darinya. ${ }^{90}$

Bonar Hutapea yang melakukan penelitian di Bekasi Timur bahkan sampai pada kesimpulan bahwa pernikahan beda agama melahirkan kehidupan rumah tangga yang tidak bahagia. Kalaupun rumah tangga mereka tetap langgeng, faktor kuncinya adalah sematamata komitmen individual untuk mempertahankan pernikahan mereka. Oleh sebab itu, mereka yang melakukan pernikahan beda agama, memiliki harapan agar anak mereka tidak melakukan pernikahan beda agama seperti yang mereka lakukan. ${ }^{91}$

Jika mengacu pada fakta-fakta tersebut, menjadi wajar jika seluruh agama mempersoalkan pernikahan model ini, sebagaimana dikemukakan Sri Wahyuni. Sekalipun ia menuntut agar pernikahan beda agama yang banyak terjadi di Indonesia mendapatkan "penyelesaian hukum", ia menyatakan agama-agama yang hidup di Indonesia tidak ada yang membenarkan pernikahan model ini, baik Islam, Katolik, Protestan, Hindu, ataupun Buddha. ${ }^{92}$

Pertimbangan utama pelarangan tentu faktor akidah. Oleh sebab itu, keputusan 'Umar b. Khațtâb yang memerintahkan Hudhayfah menceraikan istrinya yang Yahudi karena dikhawatirkan masuk dalam komunitas non-Muslim ${ }^{93}$ sangat masuk akal. Jika sekelas sahabat besar seperti Hudhayfah saja masih dinilai mengkhawatirkan, apalagi hanya kelas orang biasa. Oleh sebab itu, penggunaan sadd al-dharîa

${ }^{89}$ Calvina dan Elvi Andriani Yusuf, "Konflik Pemilihan Agama pada Remaja dari Perkawinan Beda Agama”, Jurnal Predicara, Vol. 2, No. 1 (Desember 2012).

90 Zainul Mu'ien Husni, "Pernikahan Beda Agama dalam Perspektif al-Qur'ân dan Sunnah serta Problematikanya", at-Turâs: Jurnal Studi Keislaman, Vol. 2, No. 1 (Januari-Juni 2015), 99.

91 Bonar Hutapea, "Dinamika Penyesuaian Suami-Istri dalam Pernikahan Berbeda Agama”, Jurnal Penelitian dan Pengembangan Kesejabteraan Sosial, Vol. 16 No. 01 (2011). 92 Sri Wahyuni, "Kontroversi Perkawinan Beda Agama di Indonesia", Jurnal Hukum Islam, Vol. 8, No. 1 (Juni 2010).

${ }^{93}$ Sirry (ed.), Fiqih Lintas Agama, 162. 
(melarang sesuatu dalam rangka menghindari mafsadab) sebagaimana dilakukan 'Umar" nampaknya menjadi pilihan paling masuk akal demi melindungi akidah yang merupakan kemaslahatan tertinggi.

Riḍâ pun yang pemikirannya sangat mewarnai bahkan menjadi rujukan utama Paramadina mengecam keras pernikahan para Muslim yang buruk akhlaknya yang menyebabkan mereka mengikuti agama pasangannya seperti yang banyak terjadi di Eropa. Dalam kondisi seperti ini menurutnya penggunaan sadd al-dhari $a h$ merupakan pilihan yang tidak bisa dielakkan. ${ }^{95}$ Artinya, Rị̂â pun sepakat bahwa persoalan akidah tetap harus dijadikan pertimbangan utama. Pertimbangan akidah itu pula yang nampaknya menjadi pertimbangan utama ketentuan yang berlaku di Indonesia.

\section{Penutup}

Ijtihad Paramadina terkait pernikahan beda agama merupakan sebuah gagasan baru yang hampir tidak pernah dikemukakan ulama lain sebelumnya. Dalam pandangan Paramadina, setiap Muslim, baik laki-laki maupun perempuan semestinya diberikan kebebasan untuk menikah dengan non-Muslim, apapun agama dan aliran kepercayaan yang dianutnya. Ijtihad ini setidaknya berangkat dari dua asumsi dasar. Pertama, hanya musyrik Arab yang haram dinikahi, sementara hampir bisa dipastikan jenis kepercayaan tersebut saat ini sudah tidak ada. Kedua, seluruh agama dan aliran kepercayaan yang ada saat ini merupakan agama samawi dan penganutnya disebut Ahli Kitab.

Ijtihad ini lebih tertuju pada pertimbangan muamalah, yakni terciptanya kerukunan antar-umat beragama, dan cenderung mengabaikan kepentingan akidah. Sekalipun pernikahan beda agama dapat mewujudkan kerukunan umat beragama, namun di sisi lain tak dapat dipungkiri bahwa pernikahan tersebut dapat merusak akidah. Mengingat akidah merupakan kemaslahatan paling utama, penggunaan sadd al-dharí $a b$ menjadi pilihan yang paling masuk akal.

\section{Daftar Rujukan}

Abâdî, Abû al-Ṭayyib Muhammad Shams al-Haq. 'Awn al-Ma'bûd: Sharb Sunan Abî Dâwud, Vol. 8. Madinah: al-Maktabah al-Salafiyah, 1968.

'Âshûr, Muhammad al-Ṭâhir. Tafsîr al-Taḥrîr wa al-Tanwîr, Vol. 8. Tunis: al-Dâr al-Tûnisiyah li al-Nashr, 1984.

\footnotetext{
94 Tim Majallah, Mujamma' al-Fiqh al-Islâmî, 9, 1319 dan 1653.
}

${ }^{95}$ Riḍ̂a, Tafsîr al-Mannâr, Vol. 6, 160. 
'Awayîsah (al), Huusayn b. 'Awdah. al-Mawsû́ah al-Fiqhîah alMuyassarah fì Figh al-Kitâb wa al-Sunnah al-Mutahbarah, Vol. 5. Beirut: al-Maktabah al-Islâmîyah Dâr Ibn Hazm, 1429.

Buchori, Abdusshomad et.al. 101 Masalah Hukum Islam: Sebuah Produk Fatwa Majelis Ulama Indonesia. t.t.: MUI Jatim dan Pusataka Dai Muda, 2003.

Calvina dan Yusuf, Elvi Andriani. "Konflik Pemilihan Agama pada Remaja dari Perkawinan Beda Agama", Jurnal Predicara, Vol. 2, No. 1, Desember 2012.

Darwish, Muhy al-Dîn b. Aḥmad Muṣtafâ. I'râb al-Qur'ân wa Bayânuh, Vol. 10. Beirut: Dâr al-Irshâd, 1415.

Ḥakîm, 'Abd al-Ḥamid. al-Bayân, Vol. 3. Jakarta: Maktabah al-Sa'diyah Putra, t.th.

Harasî (al), al-Kayyâ. Aḥkâm al-Qur'ân, Vol. 1. Beirut: Dâr al-Kutub al'Ilmîyah, 1405.

Hosen, Ibrahim. "Perkawinan Antar Agama menurut Hukum Islam", dalam Dadang Hawari $\mathrm{dkk}$, Persiapan menuju Perkawinan yang Lestari. Jakarta: Pustaka Antara, 1993.

http:// paramadina.or.id/, diakses tanggal 29 Juni 2015 http://www.hukumonline.com/berita/baca/lt55828be906c8b/inilahbabak-akhir-judicial-review-kawin-beda-agama, diakses tgl 20 Juni 2015.

https://id.wikipedia.org/wiki/Yayasan_Paramadina, diakses tanggal 29 Juni 2015.

Husni, Zainul Mu'ien. "Pernikahan Beda Agama dalam Perspektif alQur'ân dan Sunnah serta Problematikanya", at-Turâs: Jurnal Studi Keislaman, Vol. 2, No. 1, Januari-Juni 2015.

Hutapea, Bonar. "Dinamika Penyesuaian Suami-Istri dalam Pernikahan Berbeda Agama", Jurnal Penelitian dan Pengembangan Kesejabteraan Sosial, Vol. 16 No. 01, 2011.

Jawa Pos, Semua Instansi Dilarang Layani Nikah Beda Agama, 22 Juni 2015.

Kathîr, Abû al-Fidâ' Ismâ'îl b. 'Umar b. Tafsîr al-Qur'ân al-'Ažîm, Vol. 1. t.t.: Dâr Ṭaybah li al-Nashr wa al-Tawzî‘.

Lakhmî (al), 'Alî b. Muhammad al-Rubâî̀. al-Tabsirah, Aḥmad Abd Karîm Najî̉b (ed.), Vol. 5. Qatar: Wizârat al-Awqâf wa al-Shu'ûn al-'Arabîyah, 2011.

Majallah, Tim. Mujamma' al-Fiqh al-Islâmî al-Tabi‘ li Munaz̧amat alMu'tamar al-Islâmî bi Jiddah, 9. 
Qummâsh (al), 'Abd Rạ̣mân b. Muhammad. al-Hâwî fî̀ Tafsîr alQur'ân al-Karim. t.t.: t.p., 2009.

Qurtubî (al), Abû 'Umar Yûsuf b. 'Abd Allah b. Muhammad b. 'Abd al-Barr b. 'Âșim. al-Kâfî fî Fiqh Ahl al-Madînah al-Mâlikề, Vol. 2. Riyad: Maktabah Riyâd al-Hadîthah, 1980.

Râzî (al), Fakhr al-Dîn. Mafâtị̣ al-Ghayb, Vol. 6. Beirut: Dâr Ihyầ' alTurâth al-'Arabî, t.th.

Riḍ̂, Muhammad Rashîd. Tafsîr al-Mannâr, Vol. 6. Kairo: al-Hay’ah alMișriyah al-'Âmmah li al-Kitâb, 1990.

Sâbûnî (al), Muhammad 'Alî. Rawầ'i' al-Bayân: Tafsîr Âyât al-Aḥkâm, Vol. 1. Damaskus: Muassasat Manâhil al-'İrfân, 1980.

Sâbiq, Sayyid. Fiqh al-Sunnah, Vol. 2. Beirut: Dâr al-Fikr, 2008.

Sarakhsî (al), Muhammad b. Aḥmad b. Abî Sahl Shams al-Aimmah. alMabsût, Vol. 34. t.t.: t.p., t.th.

Shîrâzî (al), Abû Ishâa Ibrâhîm b. 'Alî b. Yûsuf. al-Mubadhdhab fî Fiqh al-Imâm al-Shâfî̀, Vol. 2. Beirut: Dâr al-Fikr, 1994.

Shihab, M. Quraish. Tafsir al-Mishbah, Vol. 1. Jakarta: Lentera Hati, 2007.

-----. Wawasan al-Qur'an: Tafsir Tematik atas Pelbagai Persoalan Umat. Bandung: Mizan, 1998.

Sirry, Mun'im A. "Kawin Beda Agama”, dalam Mun'im A. Sirry (ed.), Fiqib Lintas Agama, Membangun Masyarakat Inklusif-Pluralis. Jakarta: Yayasan Wakaf Paramadina, 2004.

Tabarî (al), Abû Ja'far. Jâmi' al-Bayân fì Ta'wîl al-Qur'ân, Vol. 4. t.t.: Mu'assasat al-Risâlah, 2000.

Wahyuni, Sri. "Kontroversi Perkawinan Beda Agama di Indonesia", Jurnal Hukum Islam, Vol. 8, No. 1, Juni 2010.

Zuhaylî (al), Wahbah. al-Figh al-Islâmî wa Adillatuh, Vol. 9. Damaskus: Dâr al-Fikr, 2004.

----- al-Tafsîr al-Munîr fî al-'Aqîdah, wa al-Sharî'ah wa al-Manbaj, Vol. 2. Damaskus: Dâr al-Fikr, 1418.

----. Usûl al-Fiqh al-Islâmî, Vol. 1. Beirut: Dâr al-Fikr al-Mu'âṣir, 2001. 